\title{
21. HEAVY MINERALS FROM PALEOGENE SEDIMENTS, DEEP SEA DRILLING PROJECT LEG 81: THEIR BEARING ON STRATIGRAPHY, SEDIMENT PROVENANCE, AND THE EVOLUTION OF THE NORTH ATLANTIC ${ }^{1}$
}

\author{
Andrew C. Morton, British Geological Survey, Keyworth ${ }^{2}$
}

\begin{abstract}
Five heavy mineral associations occur in the Paleocene and Eocene sediments recovered during Leg 81 of the Deep Sea Drilling Project (DSDP) in the SW Rockall area. Association 1, consisting of augite, iddingsite, and olivine, was derived from the basaltic rocks of the northern part of the Rockall Plateau. Association 2 consists of epidote group minerals, including piedmontite, and amphiboles of actinolite, actinolitic hornblende, and magnesio-hornblende compositions, and was derived from the metamorphic basement of south Greenland. Association 3 comprises garnet, augite, apatite, and edenitic and pargasitic amphiboles and has a provenance in the southern Rockall Plateau. Associations 4 (garnet, apatite, edenitic/pargasitic amphiboles) and 5 (garnet, apatite) are intrastratal solution derivatives of Association 3, with successive removal of first pyroxene and then amphibole with increasing depth of burial.

Throughout the SW Rockall Plateau area there is a significant change in the spectrum of the above assemblages in the lower part of the Eocene. This change has been noted at Sites 403, 404, 553, and 555 and is defined by the last appearance of Association 2. This level therefore marks the cessation of sediment supply from southern Greenland and is the result of the final separation of Rockall and Greenland immediately prior to magnetic Anomaly 24 .
\end{abstract}

\section{INTRODUCTION}

Of the four sites drilled during Leg 81 of the Deep Sea Drilling Project (DSDP) SW Rockall Plateau, three (Sites 552,553 , and 555) encountered sand-grade terrigenous sediments of Paleocene to Eocene age (Fig. 1). Previous work on the heavy minerals of Paleogene sediments drilled during DSDP Leg 48 in the same area (Harrison et al., 1979) indicated that major changes in sediment supply took place during the interval related to the onset of seafloor spreading between Rockall and Greenland. The purpose of this study was to discover whether similar heavy mineral changes occur within the Leg 81 sediments, to elucidate more fully the sediment source areas, and to consider the factors controlling heavy mineral distribution.

\section{METHOD OF ANALYSIS}

Heavy minerals were extracted from the $3 \emptyset-4 \emptyset(63-125 \mu \mathrm{m})$ sand fraction by gravity-settling in bromoform of s.g. 2.80 , following disaggregation using an ultrasonic probe. Three carbonate-cemented samples from Hole 553A were treated with dilute $\mathrm{HCl}$ to aid disaggregation. Although this evidently caused partial dissolution of apatite grains, as shown by the development of etch features on grain surfaces, apatite proportions have not been significantly reduced in terms of grain count.

The resulting heavy mineral separates were examined optically; nonopaque detrital heavy mineral proportions were estimated by counting 200 grains using the ribbon method of Galehouse (1971). The composition of some of the heavy mineral groups present, particularly the amphiboles, was investigated by electron microprobe, using an energydispersive X-ray analyzer, and the surface textures of some grains were examined under an ISI60a scanning electron microscope.

\footnotetext{
${ }^{1}$ Roberts, D. G., Schnitker, D., et al., Init. Repts. DSDP, 81: Washington (U.S. Govt. Printing Office).

Address: British Geological Survey, Keyworth, Nottingham NG12 5GG, United Kingdom.
}

\section{HEAVY MINERAL ASSEMBLAGES}

The nonopaque heavy minerals identified during the study are allanite, andalusite, anatase, apatite, augite, clinozoisite, epidote, garnet, hornblende, hypersthene, iddingsite, kyanite, olivine, piedmontite, rutile, sphene, spinel, tourmaline, tremolite, and zircon. Their abundances are shown in Tables 1-3. The varieties present are similar in most respects to those described by Harrison et al. (1979) from the Leg 48 material, and further description is not warranted. However, four additional points should be made.

1. Iddingsite was not encountered in the Leg 48 sediments because of incomplete sampling, but it is an important member of some assemblages from the Leg 81 material. It occurs as deep red rounded or subrounded grains which have variable extinction and birefringence, some with wavy extinction patterns. Where the extinction is well developed, birefringence is moderate or strong. Iddingsite is not a mineral in the strictest sense, in that it does not have a definite structure and chemical composition (Gay and le Maitre, 1961), but the range in composition shown by the grains analyzed in this study (Table 4) is not dissimilar to the range of iddingsite compositions given by Ross and Shannon (1925) and Gay and le Maitre (1961).

2. The second point concerns the clinopyroxene encountered in the Leg 81 sediments. Two types, I and II, can be distinguished on optical grounds. Type I is commonly green or brown, ranging to dark brown or purplish brown in color, the more strongly-colored varieties being slightly pleochroic, with some grains enclosing plagioclase laths. Type II is predominantly colorless, pale pink or pale green, and strongly resembles the variety diallage, as described by $\operatorname{Kerr}(1959$, pp. 308-309). Type I occurs at all sites, but type II, although the dominant 


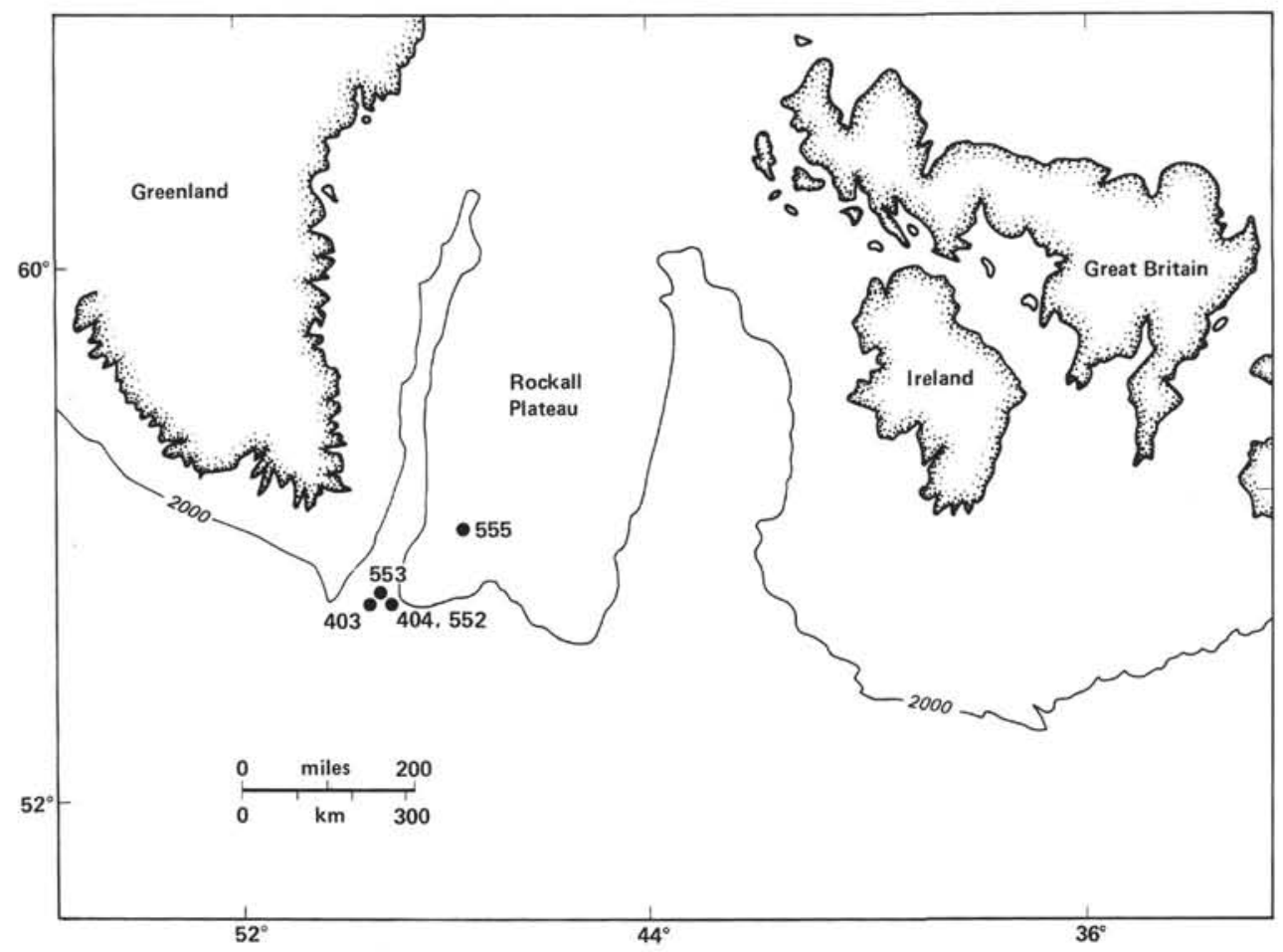

Figure 1. Paleogeographical reconstructions of the North Atlantic at Anomaly 24 time, after Roberts et al. (1979), showing locations of the DSDP holes discussed in this chapter.

Table 1. Results of heavy mineral analyses of samples from DSDP Leg 81, Site 552. Proportions of heavy minerals denoted in percentages; those below $0.5 \%$ are represented as $\mathrm{R}$ (rare). Figures in parentheses denote actual grain count and are shown for samples with less than 100 detrital grains.

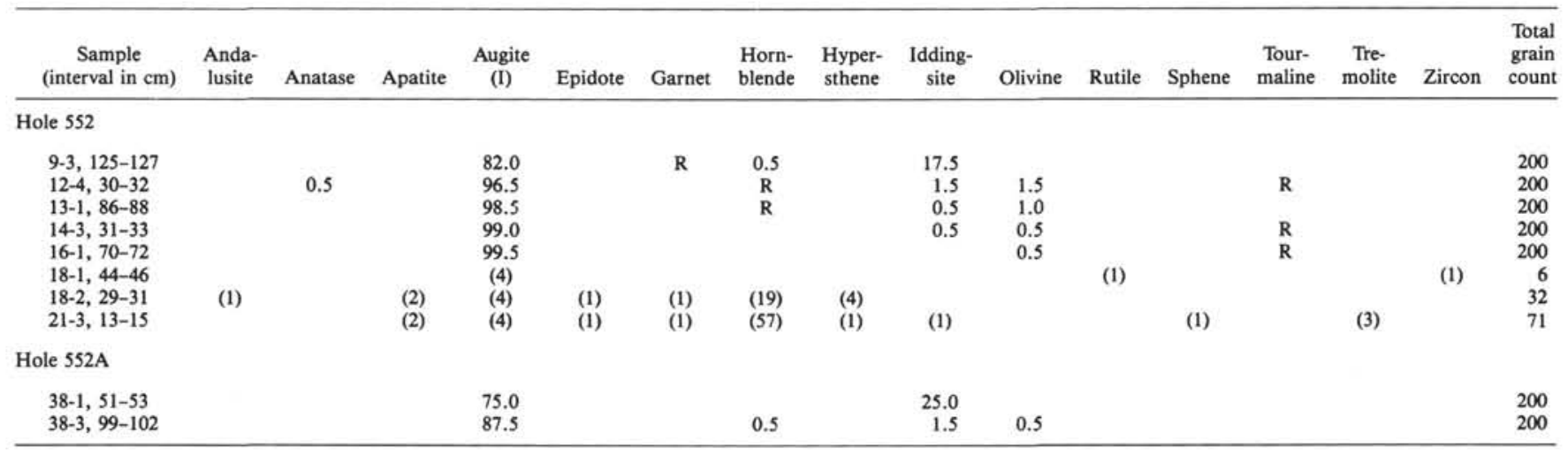

Table 2. Results of heavy mineral analyses of samples from DSDP Leg 81, Site 553. (See Table 1 for explanation.)

\begin{tabular}{|c|c|c|c|c|c|c|c|c|c|c|c|c|c|c|c|c|c|c|c|c|c|}
\hline $\begin{array}{c}\text { Sample } \\
\text { (interval in } \mathrm{cm} \text { ) }\end{array}$ & $\begin{array}{l}\text { Alla- } \\
\text { nite }\end{array}$ & Anatase & $\begin{array}{l}\text { Anda- } \\
\text { lusite }\end{array}$ & Apatite & $\begin{array}{l}\text { Augite } \\
\text { (I) }\end{array}$ & $\begin{array}{l}\text { Clino- } \\
\text { zoisite }\end{array}$ & Epidote & Garnet & $\begin{array}{l}\text { Horn- } \\
\text { blende }\end{array}$ & $\begin{array}{l}\text { Hyper- } \\
\text { sthene }\end{array}$ & $\begin{array}{l}\text { Idding- } \\
\text { site }\end{array}$ & Kyanite & Olivine & $\begin{array}{c}\text { Pied. } \\
\text { montite }\end{array}$ & Rutile & Sphene & Spinel & $\begin{array}{l}\text { Tour- } \\
\text { maline }\end{array}$ & $\begin{array}{l}\text { Tre: } \\
\text { molite }\end{array}$ & Zircon & $\begin{array}{l}\text { Total } \\
\text { grain } \\
\text { count }\end{array}$ \\
\hline \multicolumn{22}{|l|}{ Hole 553A } \\
\hline $10-7,48-50$ & & & & $\mathbf{R}$ & 85.0 & & & & 0.5 & & 14.5 & & & & & & & & & & 200 \\
\hline $11-5,27-28$ & & & & 0.5 & 97.0 & & 0.5 & & 1.0 & & 1.0 & & & & & & & & & & 200 \\
\hline $12-1,25-26$ & & & & & 98.0 & & & & 1.0 & & 0.5 & & 0.5 & & & & & & & & 200 \\
\hline $12-3,142-144$ & & 0.5 & & 4.5 & 1.0 & 0.5 & 11.5 & 2.0 & 65.5 & & & & & & 0.5 & 3.0 & & & 8.5 & 2.5 & 168 \\
\hline $13-1,82-85$ & & & & (2) & (10) & (1) & (36) & (1) & (40) & & & & & & & (3) & & (1) & & (2) & 96 \\
\hline $13-2,90-92$ & & 1.0 & 1.0 & 4.0 & 6.0 & 2.5 & 19.5 & 2.0 & 55.0 & & & & & & & 2.0 & & 2.0 & 2.5 & 2.5 & 116 \\
\hline $14-3,116-118$ & & 0.5 & & 3.5 & 1.5 & 1.5 & 27.5 & 0.5 & 59.5 & & & & & & & 4.0 & & & 1.0 & 0.5 & 200 \\
\hline $15-1,127-129$ & & 0.5 & 0.5 & $6: 0$ & 1.0 & 1.5 & 32.0 & 0.5 & 51.0 & & & & & $\mathbf{R}$ & & 4.5 & & 1.0 & 1.0 & 0.5 & 200 \\
\hline $18-2,24-25$ & & 0.5 & 0.5 & 2.5 & 2.0 & 1.0 & 14.0 & 1.0 & 70.0 & 0.5 & & 0.5 & & 0.5 & & 2.5 & & 1.0 & 2.0 & 1.5 & 200 \\
\hline $19-2,90-91$ & & & 1.0 & 2.0 & 2.5 & 1.5 & 15.5 & 1.5 & 71.5 & 0.5 & & & & $\mathbf{R}$ & & 1.5 & & 0.5 & 1.5 & 0.5 & 200 \\
\hline $20-2,118-120$ & & 0.5 & & 3.0 & 1.0 & 0.5 & 10.5 & 0.5 & 75.0 & $\mathbf{R}$ & & & & & & 2.5 & & 0.5 & 5.0 & 1.0 & 200 \\
\hline $22-5,75-76$ & & 1.0 & & 7.0 & 0.5 & 1.0 & 14.0 & 2.0 & 67.5 & $\mathrm{~K}$ & & & & $\mathbf{R}$ & & 1.5 & & 1.5 & 3.5 & 0.5 & 200 \\
\hline $24-2,14-17$ & $\mathbf{R}$ & 0.5 & R & 2.5 & 0.5 & 1.0 & 16.5 & 0.5 & 67.5 & & & & & & 0.5 & 5.0 & & 0.5 & 4.0 & 1.0 & 200 \\
\hline $26-1,116-118$ & & & 0.5 & 6.5 & 1.0 & 2.5 & 25.0 & 1.0 & 57.5 & 0.5 & & & & $\mathbf{R}$ & & 2.0 & & 0.5 & 2.5 & 0.5 & 200 \\
\hline $28, \mathrm{CC}$ & & 0.5 & 0.5 & 5.5 & 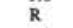 & 1.5 & 17.5 & 1.0 & 66.5 & $\mathrm{R}$ & & & & 0.5 & 0.5 & 0.5 & & 1.5 & 3.0 & 1.0 & 200 \\
\hline $29, \mathrm{CC}$ & & 0.5 & 0.5 & 2.0 & 1.0 & 2.0 & 23.0 & 0.5 & 65.0 & 0.5 & & & & & & 1.0 & $\mathbf{R}$ & $\mathrm{R}$ & 3.0 & 0.5 & 200 \\
\hline $32, \mathrm{CC}$ & & 0.5 & $\mathbf{R}$ & 1.0 & 0.5 & 2.5 & 30.0 & 1.5 & 57.5 & & & & & & & 3.0 & & 0.5 & 3.0 & 1.0 & 200 \\
\hline $34-1,9-13$ & & & 0.5 & 1.5 & & 2.0 & 18.5 & 1.5 & 69.5 & & & & & 0.5 & & 1.5 & $\mathbf{R}$ & 0.5 & 3.0 & 1.0 & 200 \\
\hline $36-2,46-48$ & & 1.0 & & 2.5 & & 1.5 & 25.0 & & 64.5 & & & & & & & 2.5 & & & 2.0 & 1.0 & 200 \\
\hline
\end{tabular}


Table 3. Results of heavy mineral analyses of samples from DSDP Leg 81. Site 555. (See Table 1 for explanation.)

\begin{tabular}{|c|c|c|c|c|c|c|c|c|c|c|c|c|c|c|c|c|c|c|c|c|}
\hline $\begin{array}{c}\text { Sample } \\
\text { (interval in } \mathrm{cm} \text { ) }\end{array}$ & $\begin{array}{l}\text { Alla- } \\
\text { nite }\end{array}$ & Anatase & $\begin{array}{l}\text { Anda- } \\
\text { lusite }\end{array}$ & Apatite & $\begin{array}{l}\text { Augite } \\
\text { (I) }\end{array}$ & $\begin{array}{l}\text { Augite } \\
\text { (II) }\end{array}$ & $\begin{array}{l}\text { Clino- } \\
\text { zoisite }\end{array}$ & Epidote & Garnet & $\begin{array}{l}\text { Horn- } \\
\text { blende }\end{array}$ & $\begin{array}{l}\text { Hyper- } \\
\text { sthene }\end{array}$ & $\begin{array}{l}\text { Idding- } \\
\text { site }\end{array}$ & Olivine & $\begin{array}{c}\text { Pied- } \\
\text { montite }\end{array}$ & Rutile & Sphene & $\begin{array}{l}\text { Tour- } \\
\text { maline }\end{array}$ & $\begin{array}{l}\text { Tre- } \\
\text { molite }\end{array}$ & Zircon & $\begin{array}{l}\text { Total } \\
\text { grain } \\
\text { count }\end{array}$ \\
\hline \multicolumn{21}{|l|}{ Hole 555} \\
\hline $27-1,0-15$ & & & & 5.0 & 1.5 & & $\mathbf{R}$ & 0.5 & 53.5 & 27.5 & $\mathbf{R}$ & 6.5 & $\mathbf{R}$ & & $\mathbf{R}$ & 2.5 & 2.0 & 0.5 & $\mathbf{R}$ & 200 \\
\hline $27-2,4-6$ & & & & 1.5 & 37.5 & 17.5 & & & 33.0 & 8.5 & 1.0 & 0.5 & & & & R & & & 0.5 & 200 \\
\hline $28-1,12-14$ & & & & 4.0 & 5.0 & 6.0 & $\mathbf{R}$ & 1.5 & 72.0 & 10.0 & 0.5 & & & & & $\mathbf{R}$ & & & 1.0 & 200 \\
\hline $30, \mathrm{CC}$ & & & & 8.0 & 13.5 & 13.5 & & & 54.5 & 5.0 & 0.5 & & & & & & & & 5.0 & 200 \\
\hline $31-1,82-84$ & & 0.5 & & 11.5 & 20.0 & 42.0 & & 1.0 & 11.0 & 8.0 & 1.0 & $\mathbf{R}$ & & & & & & & 4.5 & 200 \\
\hline $31-2,12-14$ & & 0.5 & & 22.0 & 17.5 & 23.5 & & 1.0 & 24.0 & 7.5 & 0.5 & $\mathbf{R}$ & & & & & & & 3.5 & 200 \\
\hline $32-2,26-28$ & & & & 27.5 & 11.5 & 21.0 & & 0.5 & 21.0 & 15.0 & 1.5 & R & & & & 1.0 & & & 1.0 & 200 \\
\hline $33-2,102-103$ & & & $\mathbf{R}$ & 22.0 & 6.0 & 5.0 & & 7.5 & 9.0 & 45.0 & 0.5 & $\hat{\mathbf{R}}$ & & & & & $\mathbf{R}$ & & 5.0 & 200 \\
\hline $34-2,110-112$ & & & & 18.0 & & 1.0 & 0.5 & 6.0 & 15.5 & 55.0 & & $\hat{\mathbf{R}}$ & & & 0.5 & 1.0 & 0.5 & 0.5 & 1.5 & 200 \\
\hline $34-4,57-58$ & $\mathbf{R}$ & 0.5 & & 8.0 & & 2.5 & 1.5 & 24.5 & 1.0 & 57.0 & & & & $\mathbf{R}$ & & 3.0 & & 0.5 & 1.5 & 200 \\
\hline $34, C C(12-14)$ & & & & 3.5 & & 1.5 & 1.5 & 28.5 & 0.5 & 59.0 & & & & $\hat{\mathbf{R}}$ & 0.5 & 3.0 & 1.0 & 1.0 & 1.0 & 200 \\
\hline $36-1,125-127$ & & 0.5 & & 3.0 & & 1.0 & 2.0 & 23.5 & R & 63.0 & & & & $\hat{R}$ & & 4.5 & 0.5 & 2.0 & & 200 \\
\hline $38-2,62-64$ & $\mathbf{R}$ & $\mathbf{R}$ & & 4.0 & & 0.5 & 1.5 & 26.5 & 1.5 & 61.5 & & & & R & & 2.5 & 0.5 & 1.5 & & 200 \\
\hline $41-2,33-35$ & & 0.5 & & 15.0 & & 4.5 & 1.0 & 11.5 & 21.0 & 43.0 & & & & & & 1.5 & & 1.0 & 1.0 & 200 \\
\hline $44-3,103-105$ & & 0.5 & & 16.5 & & & & 2.0 & 26.0 & 57.0 & & & & & & 1.0 & & & & 200 \\
\hline $47-4,122-124$ & & 1.0 & & 12.0 & & 2.0 & & 1.5 & 27.5 & 54.5 & & & & & & 0.5 & & & 1.0 & 200 \\
\hline $51-1,12-14$ & & & & 3.5 & & 1.0 & 2.5 & 25.0 & 7.5 & 56.0 & & & & $\mathbf{R}$ & & 3.0 & & 0.5 & 1.0 & 200 \\
\hline $54-6,43-46$ & & 1.5 & & 11.0 & & & 2.0 & 23.0 & 6.0 & 45.5 & & & & & & 7.0 & & & 4.0 & 151 \\
\hline $58-2,85-88$ & & $\mathbf{R}$ & & 32.0 & & & & 1.0 & 16.0 & 48.5 & & & & & & 0.5 & & & 2.0 & 200 \\
\hline $60-6,15-18$ & & $\ddot{R}$ & & 14.0 & & & & 0.5 & 15.0 & 62.5 & & & & & & 1.5 & R & 1.0 & 1.0 & 200 \\
\hline $64-3,115-117$ & & $\mathbf{R}$ & & 15.0 & & 2.0 & & 2.5 & 17.0 & 61.0 & & & & $\mathbf{R}$ & & $\mathbf{R}$ & & & 2.5 & 200 \\
\hline $67-1,13-15$ & & $\vec{R}$ & & 16.5 & & 4.0 & & 5.0 & 23.0 & 47.5 & & & & & & 1.5 & & & 2.5 & 200 \\
\hline $69-6,45-48$ & & 0.5 & & 15.5 & & 8.5 & & 1.0 & 15.5 & 56.0 & 0.5 & & & & & 0.5 & & 0.5 & 1.5 & 200 \\
\hline $70-2,42-44$ & & & & 12.0 & & 5.0 & 0.5 & 3.5 & 15.5 & 60.5 & & & & & & 1.0 & & & 2.0 & 200 \\
\hline $84-1,38-40$ & & $\mathbf{R}$ & & 24.5 & & 0.5 & & 1.0 & 25.0 & 45.5 & & & & & & & & & 3.5 & 200 \\
\hline $87-5,12-14$ & & & & 21.0 & & & 3.0 & 37.5 & 17.5 & 5.0 & & & & $\mathbf{R}$ & & 7.0 & 5.0 & & 4.0 & 200 \\
\hline $88-5,10-13$ & & $\mathbf{R}$ & & 46.5 & & & & 2.0 & 43.5 & 1.0 & & & & & & 1.5 & & & 5.5 & 200 \\
\hline $92-2,120-123$ & & 0.5 & & 44.0 & & & & 3.5 & 45.5 & 0.5 & & & & & & 0.5 & & & 5.5 & 200 \\
\hline
\end{tabular}

Table 4. Comparison of published iddingsite compositions with those of iddingsite grains from Leg 81 sediments. Published iddingsites determined by chemical methods; those of Leg 81 determined by electron microprobe.

\begin{tabular}{ccc}
\hline Compound & $\begin{array}{c}\text { Iddingsite range } \\
\text { (Ross and Shannon, 1925; } \\
\text { Gay and le Maitre, 1961) }\end{array}$ & $\begin{array}{c}\text { Range of "iddingsite" } \\
\text { grains in this study }\end{array}$ \\
\hline $\mathrm{SiO}_{2}$ & $17.52-44.38$ & $15.46-25.97$ \\
$\mathrm{TiO}_{2}$ & $0.00-0.70$ & $1.94-4.17$ \\
$\mathrm{Al}_{2} \mathrm{O}_{3}$ & $0.00-8.00$ & $8.28-12.25$ \\
$\mathrm{Cr}_{2} \mathrm{O}_{3}$ & n.d. & $0.00-0.28$ \\
$\mathrm{Fe}_{2} \mathrm{O}_{3}$ & $20.70-57.27$ & $36.32-50.81^{\mathrm{c}}$ \\
$\mathrm{FeO}$ & $0.00-4.64$ & $0.00-0.27$ \\
$\mathrm{MnO}$ & $0.45^{\mathrm{a}}$ & $0.84-2.44$ \\
$\mathrm{MgO}$ & $2.50-24.00$ & $0.29-0.52$ \\
$\mathrm{CaO}$ & $1.64-3.60$ & $0.49-1.42$ \\
$\mathrm{Na} 2 \mathrm{O}$ & $0.18-0.31 \mathrm{~b}$ & $0.33-1.83$ \\
$\mathrm{~K} 2 \mathrm{O}$ & $0.28-0.31^{\mathrm{b}}$ & $75.76-85.06$ \\
$\mathrm{Total}$ & $81.52-95.80$ & \\
\hline
\end{tabular}

a Only one analysis determined $\mathrm{MnO}$.

b Only two analyses determined $\mathrm{Na}_{2} \mathrm{O}$ and $\mathrm{K}_{2} \mathrm{O}$.

c All Fe calculated as $\mathrm{FeO}$.

type at Site 555 , is absent from Sites 552 and 553 and from the Leg 48 sediments. However, the two types are virtually indistinguishable on compositional grounds, as determined by electron microprobe analysis (Fig. 2); therefore, in Tables 1, 2, and 3 they are termed augite and referred to as types I and II.

3. The terms hornblende and tremolite as used in Tables 1,2 , and 3 are varieties of amphibole distinguished on optical grounds, the hornblende being brown, browngreen, green, or bluish-green clinoamphibole and the tremolite being colorless clinoamphibole. Analysis of 165 amphibole grains by electron microprobe reveals strong compositional variations, from pargasite to tremoliteactinolite (Fig. 3). Two distinct amphibole populations can be delineated on compositional grounds, as discussed later.

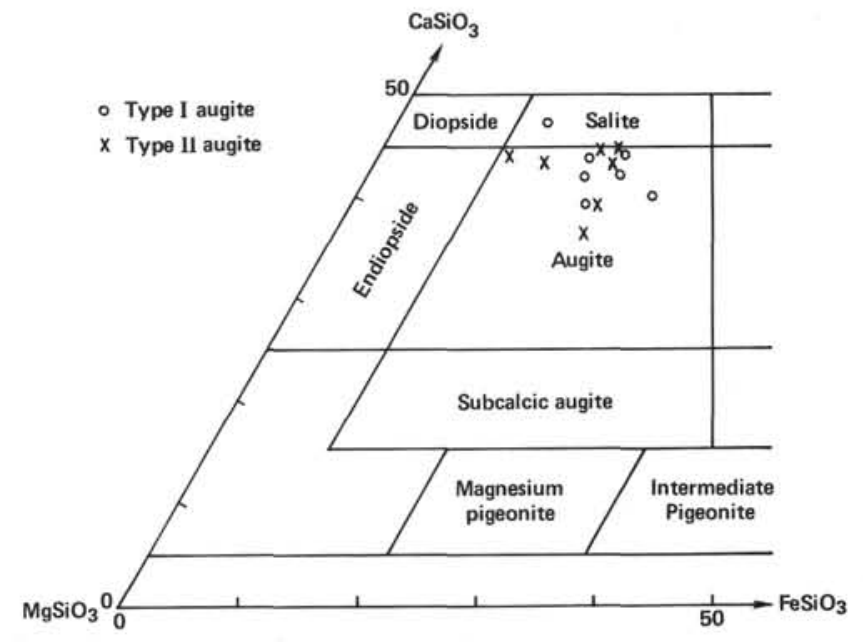

Figure 2. Variations in composition of detrital clinopyroxenes in Leg 81 sediments as determined by electron microprobe analysis. Nomenclature follows that of Poldervaart and Hess (1951).

4. The single grain of spinel encountered in the Leg 81 sediments is deep brown and is probably picotite, whereas the Leg 48 spinel is the bluish-green variety, pleonaste.

\section{HEAVY MINERAL ASSOCIATIONS}

As Tables 1, 2, and 3 show, there are major variations in heavy mineral assemblages in the Paleogene sediments recovered during Leg 81 . Particularly variable are the proportions of apatite, augite, epidote, garnet, and hornblende, and these variations define five distinct groups, or associations, as follows:

Association 1: Dominated by type I augite, commonly with iddingsite (up to $25 \%$ ) and minor olivine.

Association 2: Largely consisting of epidote group minerals (epidote, clinozoisite, and piedmontite, averaging $22.5 \%$ ) and amphiboles (bluish-green hornblende and tremolite, averaging $65.5 \%$ ). Apatite occurs in quantities 

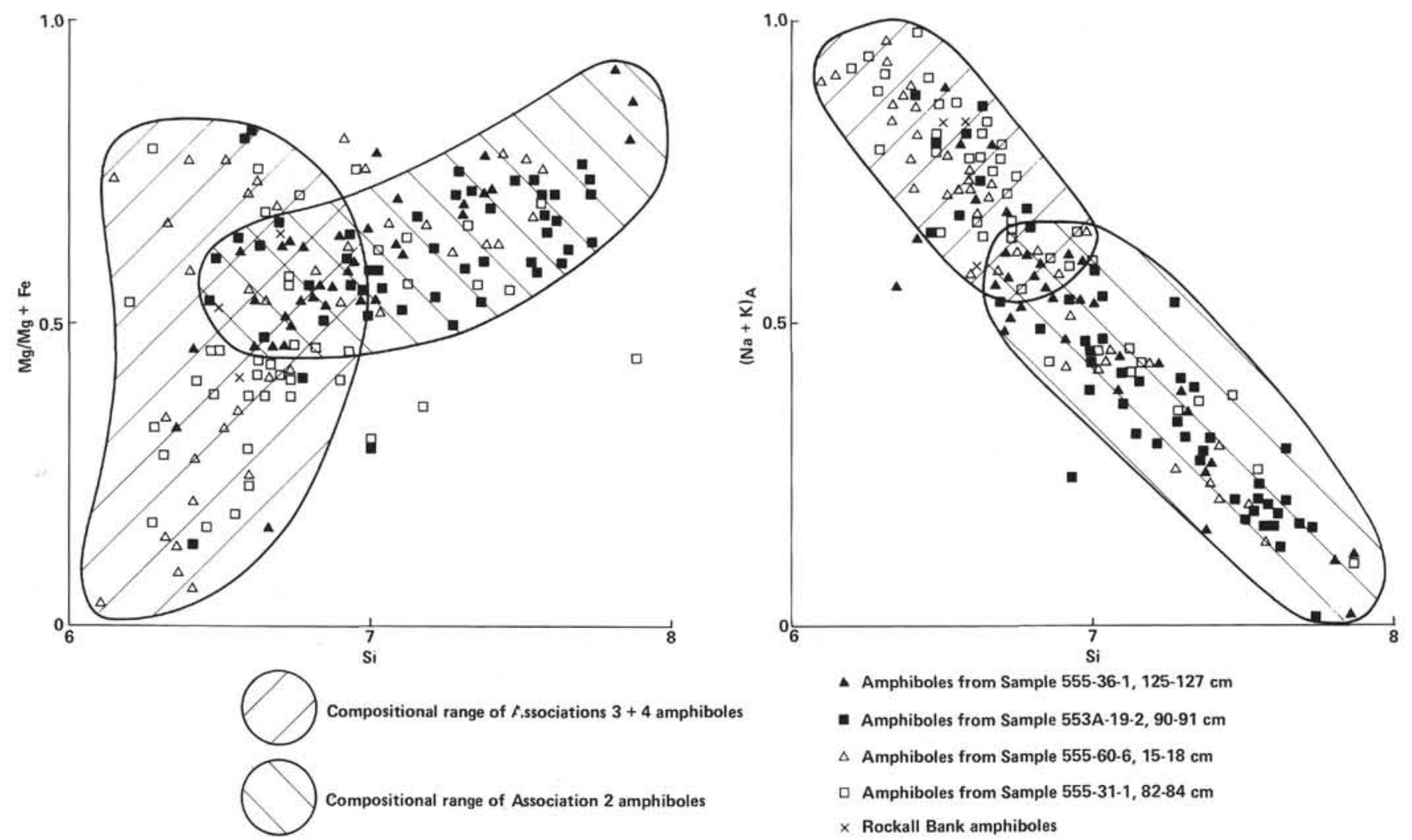

Figure 3. Compositional ranges of amphiboles from Leg 81 sediments, as determined by electron microprobe analysis.

up to $7 \%$; garnet and augite are only minor, neither exceeding $2 \%$.

Association 3: Contains type II augites, garnet, hornblende (brown or green varieties), and apatite, all present as major phases in variable proportions. Hypersthene is also present; epidote is minor, rarely exceeding $1 \%$; and piedmontite is absent.

Association 4: An apatite-garnet-hornblende association, with apatite averaging $17.5 \%$, garnet $20 \%$, and brown-green hornblende $54 \%$. Minor amounts of type II augite and hypersthene occur; most display etch features similar to those shown in Figures 4 and 5. Epidote is minor, piedmontite absent.

Association 5: An apatite-garnet association, with apatite averaging $45 \%$ and garnet $44.5 \%$. Hornblende (brown-green) is minor, and extremely etched (Fig. 6); epidote rarely exceeds $2 \%$.

Not all these associations represent sediment from different source areas. Associations 3, 4, and 5 are virtually confined to Site 555, and their distribution here is dependent on burial depth. Pyroxenes are only common above $350 \mathrm{~m}$ below the sea bed, and amphiboles become rare below $860 \mathrm{~m}$. These minerals show extreme etch features close to their critical depths (Figs. 4, 5, and 6), indicating that their disappearance downhole is the result of depth-related dissolution processes. This is substantiated by the lack of any statistically significant difference between the amphibole populations of a sample belonging to Association 3 (Sample 551-31-1, 82-84 cm) and one belonging to Association 4 (Sample 555-60-6, 15-18 $\mathrm{cm}$ ) (Table 5). It is known that burial depth is a major

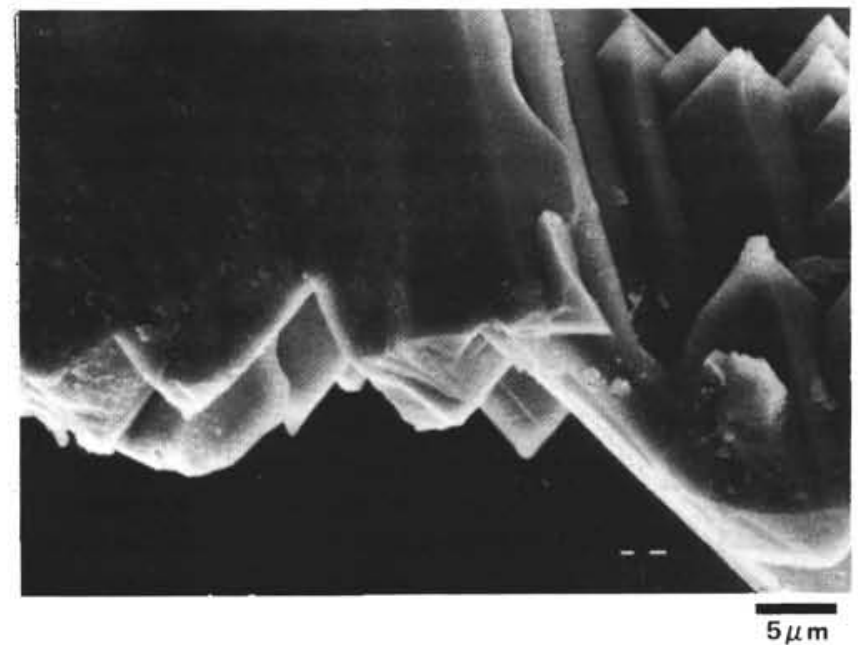

Figure 4. Augite grain showing well-developed etch facets, Sample 555-27-2, 4-6 cm.

control on intrastratal solution processes (Füchtbauer, 1970; Morton, 1979, 1982, and in press), and the order of stability shown at Site 555 (pyroxene $<$ amphibole $<$ epidote, apatite and garnet) is in full agreement with accepted orders of stability (Füchtbauer, 1970; Morton, in press).

On the other hand, there can be no doubt that Associations 1,2 , and 3 (and its diagenetic derivatives) represent genuine differences in sediment source. Association 1 is clearly different from the other two in that it con- 


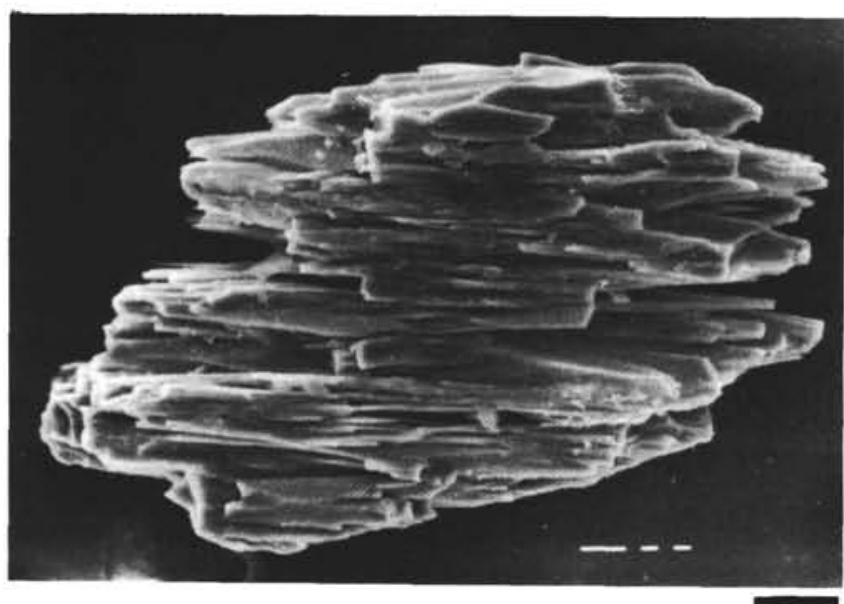

$20 \mu \mathrm{m}$

Figure 5. Hypersthene grain showing development of skeletal form, Sample 555-27-2, 4-6 cm.

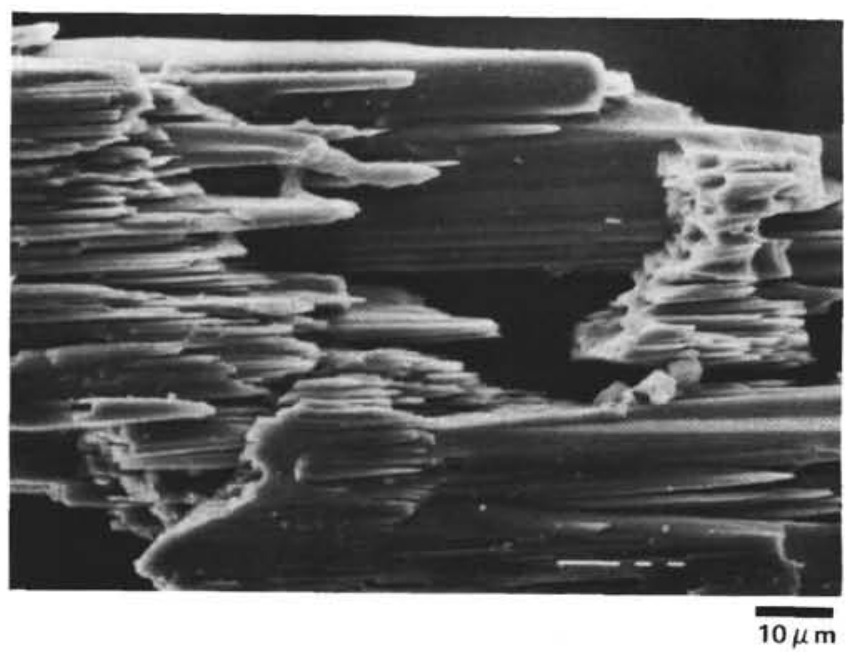

Figure 6. Highly etched amphibole grain, Sample $555-84-1,38-40 \mathrm{~cm}$.

Table 5. Average compositions of amphibole populations from the Leg 81 sediments.

\begin{tabular}{|c|c|c|c|c|c|c|c|c|}
\hline \multirow{2}{*}{$\begin{array}{c}\text { Sample } \\
\text { (interval in } \mathrm{cm} \text { ) }\end{array}$} & \multirow{2}{*}{$\begin{array}{l}\text { Heavy } \\
\text { mineral } \\
\text { associ- } \\
\text { ation }\end{array}$} & \multicolumn{2}{|c|}{$\mathrm{Si}$} & \multicolumn{2}{|c|}{$(\mathrm{Na}+\mathrm{K})_{\mathrm{A}}$} & \multicolumn{2}{|c|}{$\mathrm{Mg} / \mathrm{Mg}+\mathrm{Fe}$} & \multirow{2}{*}{$\begin{array}{l}\text { No. of } \\
\text { grains } \\
\text { analyzed }\end{array}$} \\
\hline & & M & $\mathbf{s}$ & M & $\mathrm{s}$ & M & s & \\
\hline $553 \mathrm{~A}-19-2,90-91$ & 2 & 7.173 & 0.381 & 0.405 & 0.212 & 0.610 & 0.119 & 49 \\
\hline $555-36-1,125-127$ & 2 & 6.935 & 0.374 & 0.509 & 0.186 & 0.605 & 0.147 & 36 \\
\hline $555-31-1,82-84$ & 3 & 6.722 & 0.368 & 0.665 & 0.202 & 0.475 & 0.169 & 42 \\
\hline $555-60-6,15-18$ & 4 & 6.756 & 0.418 & 0.618 & 0.240 & 0.529 & 0.231 & 38 \\
\hline Combined association 2 & & 7.073 & 0.393 & 0.449 & 0.208 & 0.608 & 0.131 & 85 \\
\hline Combined associations 3 and 4 & & 6.764 & 0.390 & 0.642 & 0.221 & 0.501 & 0.202 & 80 \\
\hline
\end{tabular}

tains mineral species not present in Associations 2 and 3. Although there are species common to Associations 2 and 3 , there are significant differences, particularly in the ratio of epidote to garnet. Epidote/epidote + garnet is consistently over 0.9 in Association 2 and consistently less than 0.1 in Associations 3, 4, and 5. Neither of these minerals has been adversely affected by intrastratal solution processes in the Leg 81 sediments, both occurring in some abundance in the most deeply buried sediments recovered (epidote group minerals exceeding $40 \%$ of the assemblage from Sample $555-87-5,12-14 \mathrm{~cm}$, and garnet exceeding $45 \%$ of the assemblage from Sample $555-92-2,120-123 \mathrm{~cm}$ ).

The primary depositional difference between the associations is further emphasized by the difference in amphibole compositions, as determined by electron microprobe analysis (Fig. 3; Table 5), with Association 2 being dominated by actinolites, actinolitic hornblendes, and magnesio-hornblendes, and Association 3 being dominated by edenites and pargasites. One hundred sixty-five detrital amphiboles were analyzed in this way, drawn from four samples, two belonging to Association 2 (Samples 553A-19-2, 90-91 cm and 555-36-1, 125-127 cm), one from Association 3 (Sample 555-31-1, 82-84 cm), and one from Association 4 (Sample 555-60-6, 15-18 $\mathrm{cm})$. Statistical treatment of the data in Table 5 indicates that there is no significant difference between the populations from Associations 3 and 4, and although the $\mathrm{Si}$ and $(\mathrm{Na}+\mathrm{K})_{\mathrm{A}}$ values are somewhat different between the two samples from Association 2, there is no significant difference in $\mathrm{Mg} / \mathrm{Mg}+\mathrm{Fe}$. The variation in $\mathrm{Si}$ and $(\mathrm{Na}+\mathrm{K})_{\mathrm{A}}$ is here attributed to the presence of a number of amphiboles of Association 3 type in the sample from Site 555, because this site is closer to the source of this association than is Site 553 (see later). Grouping the two amphibole populations indicates that on all three criteria $\left(\mathrm{Si},(\mathrm{Na}+\mathrm{K})_{\mathrm{A}}\right.$, and $\mathrm{Mg} / \mathrm{Mg}+\mathrm{Fe}$ values) the chances that the amphiboles from Association 2 and those from Associations 3 and 4 are drawn from the same population are negligible, thus confirming the view that Associations 2 and 3 were derived from different source areas.

The assemblages examined from Sites 552 and 553 belong wholly to one of the three associations without a significant degree of mixing, which makes it relatively easy to plot the changes in influence of the associations at these sites (Figs. 7, 8). This is not the case with Site 555 , where all three associations interplay to varying extents. As stated earlier, Association 2 is characterized by

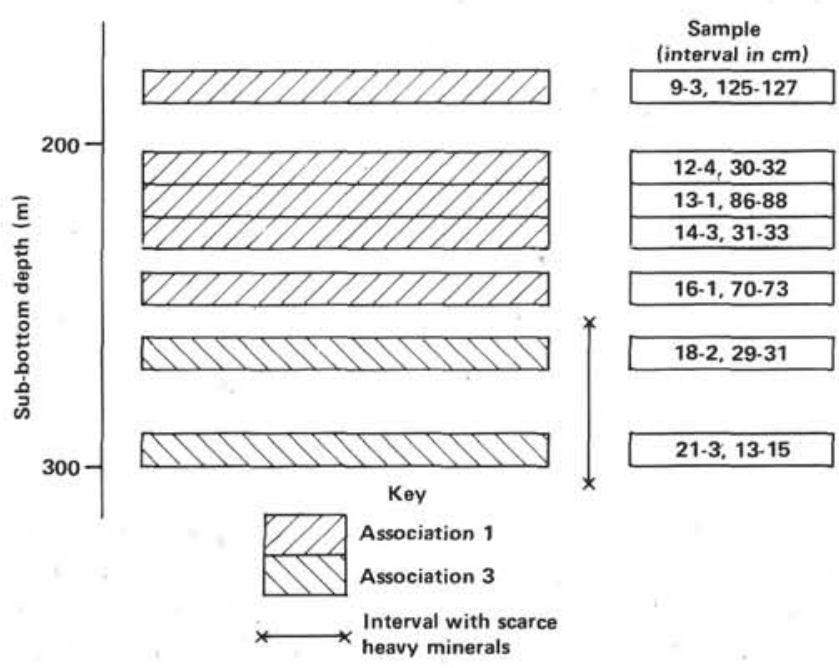

Figure 7. Distribution of heavy mineral associations at Site 552. 


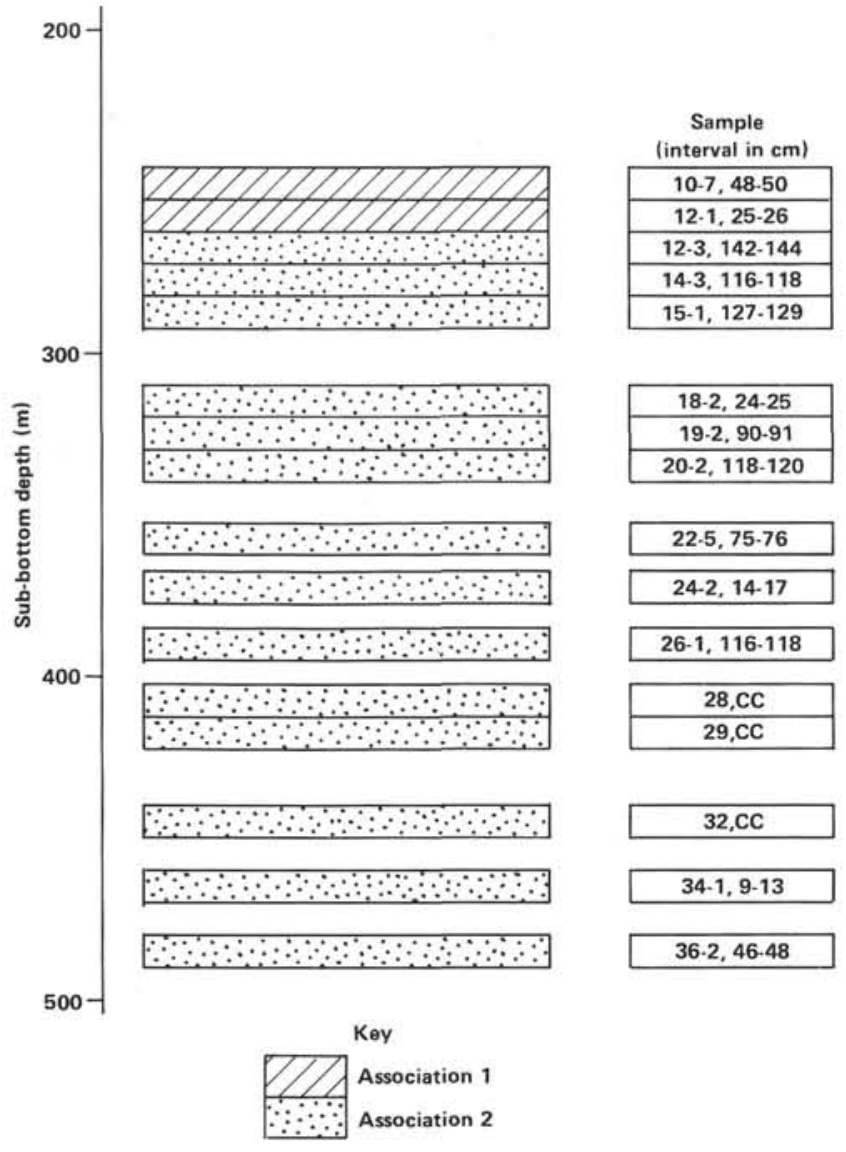

Figure 8. Distribution of heavy mineral associations at Site 553.

a higher epidote/epidote + garnet ratio $(\geq 0.9)$ than Associations 3, 4, and $5(\leq 0.1)$. The degree of interplay of the two associations in a mixed assemblage can therefore be determined by its epidote/epidote + garnet ratio (for example, the assemblage from Sample 555-41-2, $33-35 \mathrm{~cm}$ has a ratio of 0.37 , indicating that Association 2 comprises about $34 \%$ of the assemblage and Association 3, 66\%). Mixed assemblages of Association 1 and 3 are segregated by assuming the type I augite + iddingsite content to be representative of Association 1, and the rest therefore of Association 3. The relative influences of Associations 1, 2, and 3 at Site 555 are shown in Figure 9.

\section{SEDIMENT PROVENANCE}

As the preceding discussion has shown, sediment was supplied to the SW Rockall area from three separate source areas during the early Paleogene, each characterized by a distinct heavy mineral assemblage. It is, therefore, pertinent here to discuss the provenance of these associations.

\section{Association 1}

The association of augite, often enclosing plagioclase laths, with iddingsite and olivine indicates a basaltic source for Association 1, but whether it is of terrigenous or pyroclastic input is not immediately clear. Many of the as-

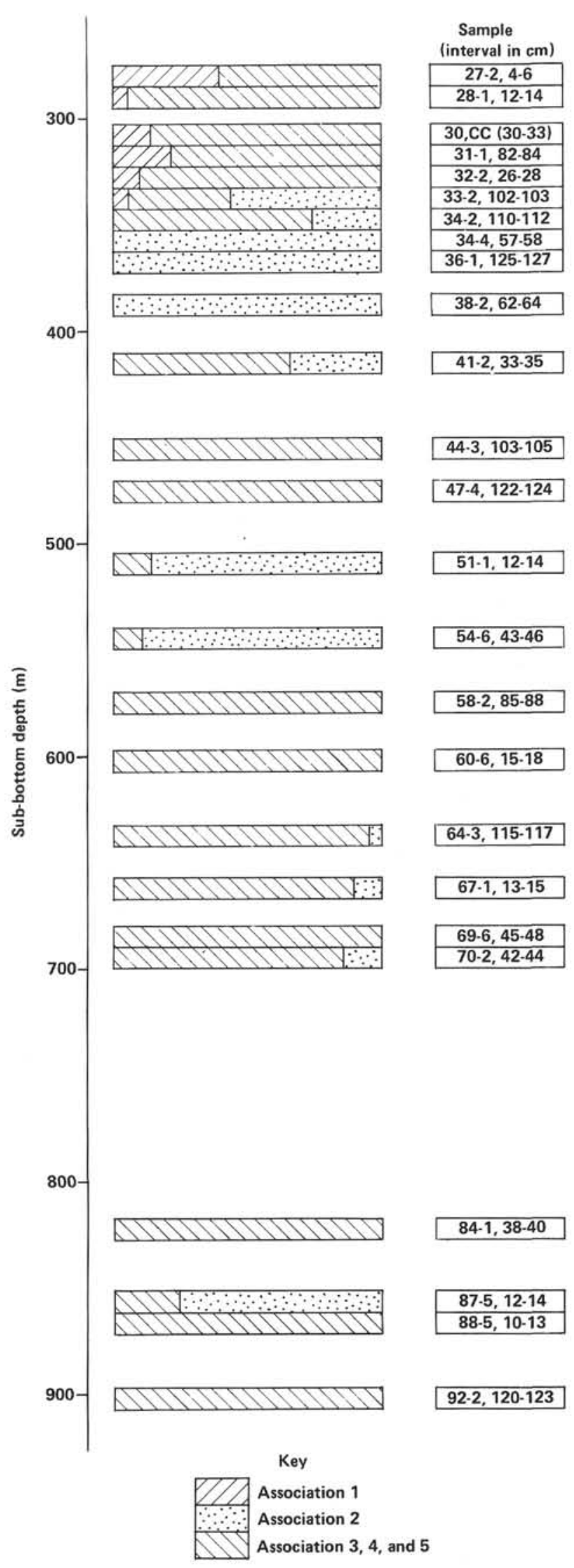

Figure 9. Distribution of heavy mineral associations at Site 555. 
sociated tuffs contain accessory augite (Morton and Keene, this volume), and one also contains iddingsite (Sample 552-19,CC). The relationship between the abundance of heavy minerals of Association 1 to that of ashfall volcanic glass is instructive in ascertaining which of these two mechanisms is the more important. This was investigated by determining the proportions of heavy mineral grains and of volcanic glass (and its alteration products) by point-counting thin sections of those sediments containing Association 1 from Site 552. It is immediately clear from the data (Table 6) that the basaltic heavy minerals are more abundant in the nonvolcanogenic sediments than in the tuffs. This impression is verified by statistical treatment: There is clearly a reciprocal relationship between the proportions of volcanic glass and of heavy minerals (correlation coefficient, $r=0.80$ ). Therefore, although it is clear from thin-section examination that some of the augite and iddingsite are of ashfall origin, it seems that the major contribution has been made by erosion of pre-existing basalts.

The interval dominated by Association 1 thickens towards the Rockall Plateau (thicker, for example, at Sites 552 and 404 than at Sites 553 or 403 ), suggesting that the sediment source lay on the plateau. Lower Tertiary basalts are known to occur in the northern parts of the Rockall Plateau (Roberts et al., 1971) and contain the augite and iddingsite that characterize Association 1 (Sabine, 1972). It seems most likely, therefore, that the sediments containing Association 1 have derived through erosion of basalts in the northern part of the Rockall Plateau.

\section{Association 2}

The association of epidote, clinozoisite, and piedmontite with amphiboles of magnesio-hornblende, actinolitic hornblende, and actinolite compositions is indicative of derivation from metamorphic basement. However, basement rocks of this mineralogy have not been recorded from the Rockall Bank, although dredging on the Lousy Bank to the north recovered glacial erratics with suitable compositions (Carruthers et al., 1923). The distribution

Table 6. Thin-section point-count data of heavy mineral and volcanic particle proportions from Site 552 , showing a good correlation between $\mathrm{V}$ and $1 / \mathrm{H}$ (correlation coefficient, $r=0.80$ ).

\begin{tabular}{lccc}
\hline \multicolumn{1}{c}{$\begin{array}{c}\text { Sample } \\
\text { (interval in cm) }\end{array}$} & $\begin{array}{c}\text { Percent } \\
\text { volcanic } \\
\text { particles } \\
\text { (V) }\end{array}$ & $\begin{array}{c}\text { Percent } \\
\text { heavy } \\
\text { minerals } \\
(\mathrm{H})\end{array}$ & $\frac{1}{\mathrm{H}}$ \\
\hline $552-9-3,125-127$ & 6 & 10 & 0.10 \\
$552-9-5,97-99$ & 15 & 3 & 0.33 \\
$552-12-2,106-108$ & 94 & 0.5 & 2.00 \\
$552-12-4,30-32$ & 10 & 8 & 0.13 \\
$552-12-7,25-27$ & 6 & 4 & 0.25 \\
$552-13-1,138-140$ & 13 & 5 & 0.20 \\
$552-14-2,127-130$ & 44 & 1 & 1.00 \\
$552-14-4,35-37$ & 36 & 1 & 1.00 \\
$552-15-1,38-44$ & 50 & 1 & 1.00 \\
$552-16-1,70-73$ & 13 & 2 & 0.50 \\
$552-17-1,23-25$ & 9 & 1 & 1.00 \\
$552-19$, CC & 29 & 3 & 0.33 \\
$552 \mathrm{~A}-37-1,123-126$ & 94 & 1 & 1.00 \\
\hline
\end{tabular}

of sediments of Association 2 also seem to argue against a Rockall source, in that they are better represented at Sites 403 and 553 to the southwest of the plateau than at Site 555, situated on the plateau.

Magnetic anisotropy studies of sediments of Association 2 indicate a derivation from the NW (Hailwood and Sayre, 1979), that is, from southern Greenland. In view of the inferred proximity of Greenland to the Rockall area (Fig. 1) during Paleocene and early Eocene times, such a source seems reasonable. Moreover, an investigation by Crommelin (1937) on modern beach sands from the south coast of Greenland revealed the presence of very similar assemblages, dominated by hornblende and epidote, even to the extent of the discovery of piedmontite in one sample. This indicates beyond all reasonable doubt that the source for Association 2 lay in southern Greenland.

\section{Association 3}

With the exception of one sample from Site 404 (Harrison et al., 1979) and two from Site 552, Association 3 has only been noted at Site 555, strongly suggesting a local source. Roberts et al. $(1972,1973)$ have shown that metamorphic basement outcrops over a wide area of the southern part of the Rockall Bank, and the cores and dredge hauls that they describe have very similar mineralogies to the sediments of Association 3. Furthermore, electron microprobe analyses of amphiboles from such cores indicate that they fall within the compositional range of Association 3 amphiboles (Fig. 3). There can be no doubt that Association 3 was derived from the metamorphic basement of the southern Rockall Bank.

\section{STRATIGRAPHY}

Apart from the obvious geographical variations in heavy mineral distribution, there are also significant stratigraphical changes. In the sediments from Leg 48 , Sites 403 and 404 , a sharp change in mineralogy was noted within the lower Eocene, from epidote-hornblende (Association 2) below to augite (Association 1) or "diopside-hypersthene" (Association 3) above (Harrison et al., 1979). The change was not seen at Site 552 because drilling was abandoned before reaching this level, but it clearly occurs at Site 553 (Fig. 5). The uppermost sample to contain a $100 \%$ Association 2 sample at Site 555 is from Sample 555-34-4, 57-58 cm (Fig. 6). At both Sites 553 and 555 this change takes place close to the NP 10/NP 11 boundary (Backman, this volume). Information from the dinoflagellates is more limited, but the occurrence of Wetzeliella meckelfeldensis above the disappearance datum of Association 2 at Site 555 (Brown and Downie, this volume) is consistent with the results from Leg 48, where the heavy mineral break lies within Zone $1 \mathrm{~b}$ of Costa and Downie (1979). It seems therefore that the disappearance of Association 2 occurred almost synchronously over the area, indicating both its value as a stratigraphic marker horizon and that a major change in sediment source took place at this time. The break is close to the base of magnetic Anomaly 24 (Fig. 10) and occurs at the base of or within the lower part of the glauconitic horizon noted by Morton et al. (this volume), which marks a major transgression over the area. This 

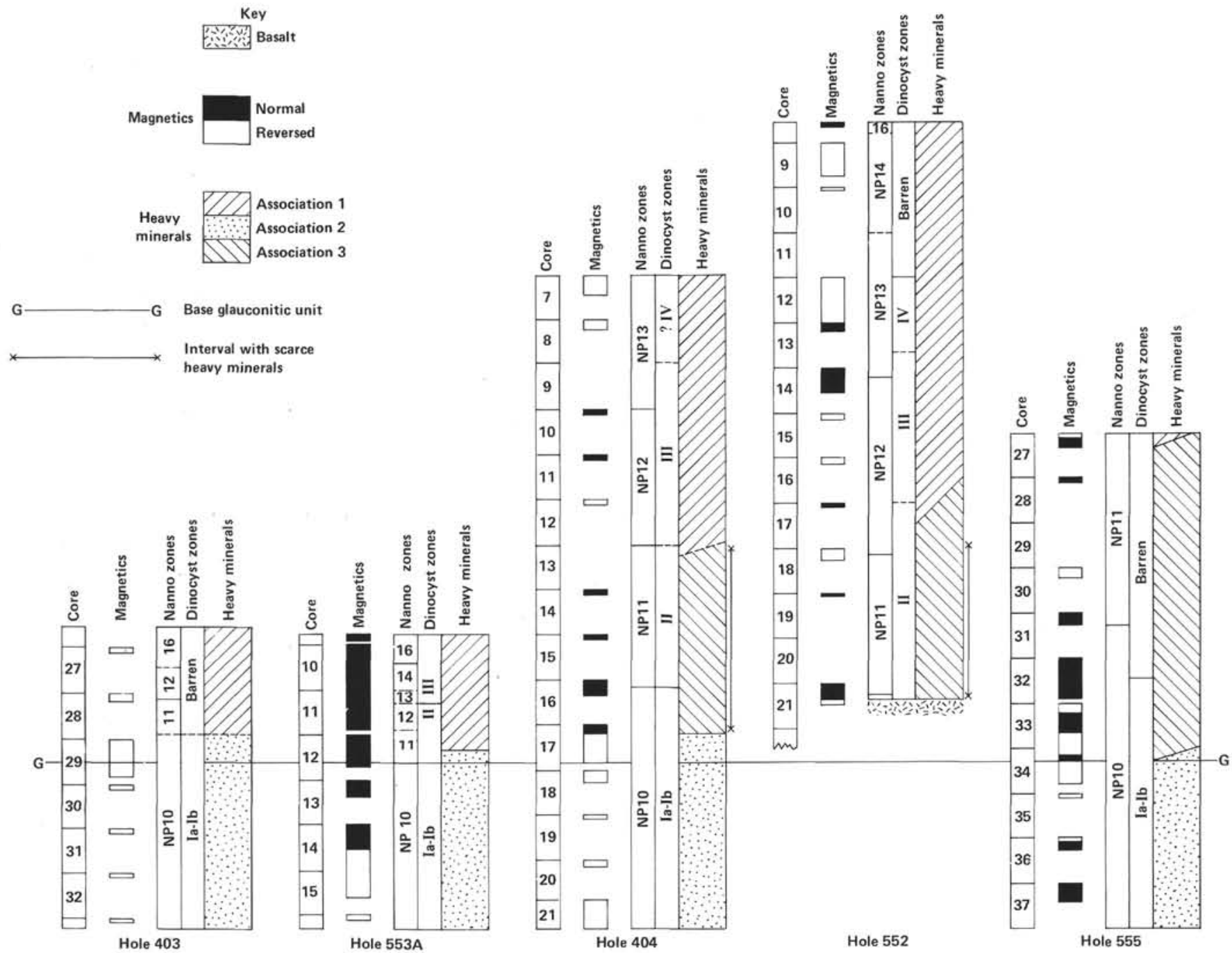

Figure 10. Correlation of lower Eocene sequences drilled during DSDP Legs 48 and 81 in the SW Rockall Plateau area. Datum level is the base of the glauconitic horizon noted by Morton et al. (this volume). Note the disappearance of heavy mineral Association 2 slightly above this level, indicating cut-off in supply from southern Greenland at this time. Nannoplankton zone assignments for Sites 552, 553, and 555 are from Backman (this volume): for the Leg 48 material, Müller's (1979) assignments have been redefined to follow the criteria used by Backman (this volume). Dinoflagellate cyst zonation follows Costa and Downie (1979) and Brown and Downie (this volume).

transgression resulted from the final separation of the Rockall and Greenland landmasses immediately prior to Anomaly 24 time (Morton et al., this volume). It is not surprising, therefore, that Greenland-derived sediments disappear from the area at about the same time. Their persistence in minor amounts to levels slightly above the base of glauconitic horizon is probably the result of reworking of underlying sediment during the major transgression referred to above.

This change is the most significant event within the lower Paleogene sequence, but two other points should be made. Above the glauconitic horizon at Sites 404 and 552 , there is a zone where heavy minerals are particularly scarce between zones where Associations 1 and 2 dominate (Fig. 10). This depletion is probably the combined effect of two factors. The first is that the major transgression will inevitably have forced back the coastline and even perhaps partially inundated the source area, thus temporarily restricting terrigenous input. The other is that the high organic productivity associated with the zone (as shown by the change from a dominantly clastic sediment below to a dominantly biogenic sediment above) has caused a relative dilution in heavy mineral content.

Below the heavy mineral break, Greenland-derived sediment is overwhelmingly dominant, to the extent that Rockall-derived material is restricted to Site 555, and even here, brief influxes of the former have occurred (Fig. 9). It is noteworthy that the intervals dominated by Greenland-derived detritus at Site 555 are precisely those characterized by a low dinoflagellate cyst content relative to pollen (Brown and Downie, this volume). Fluctuations in the dinoflagellate/pollen ratio are believed to represent fluctuations in the position of the coastline, with low dinoflagellate proportions indicating nearshore conditions, and the reverse indicating offshore conditions (Brown and Downie, this volume). On this basis the variation in dinoflagellate cyst content may be used as a local measure of relative sea level. It therefore appears that the Greenland-derived assemblages are associated with the most regressive phases, 
and that Rockall-derived assemblages appear with the transgressions. This implies that during transgressive periods there lay a shallow ephemeral seaway between Site 555 and the Greenland massif which cut off the Greenland-derived sediment (much as with the major transgression which took place in late NP10). During regressive phases the sea retreated, allowing rivers to transport the Greenland material across to Site 555. It also seems that either Site 553 lay to the west of this seaway, or that it terminated to the north of the site, because Greenland detritus dominates the entire sequence here, even where the dinoflagellate/pollen ratio rises. Insufficient geographical coverage of the area exists to distinguish between these two alternatives.

\section{CONCLUSIONS}

Five heavy mineral suites occur in the lower Paleogene sediments in the SW Rockall area. Association 1 is dominated by augite of basaltic type, with iddingsite and minor olivine. It was largely derived through erosion of basalts on the northern part of the Rockall Plateau, but a minor contribution was also made through pyroclastic volcanism.

Association 2 is characterized by epidote group minerals, including the distinctive species piedmontite, and amphiboles of magnesio-hornblende, actinolitic hornblende, and tremolite-actinolite type. The distribution of the association, its similarity to shore sands of southern Greenland, and its northwesterly derivation indicated by magnetic fabric studies all point to a source in southern Greenland.

Association 3 contains apatite, augite (diallage variety), garnet, and amphibole of edenitic and pargasitic compositions, and is similar in most respects to basement rocks drilled and dredged on the Rockall Bank. Such a derivation is consistent with its distribution, being virtually wholly confined to the Rockall Plateau Site 555.

Association 4 is identical to Association 3 in mineralogy and mineral composition, except that augite proportions are much diminished. This coincides with an increase in etching intensity on augite grains and occurs with increasing burial depth. Association 4 is therefore considered to be a diagenetically modified Association 3, with augite dissolution having taken place through burial depth-related processes.

Association 5 represents a more extreme development of the same process, with the dissolution of amphiboles producing an apatite-garnet suite. The disappearance of amphibole has taken place at a greater depth than that of augite, testifying to its greater resistance to intrastratal solution. Associations 4 and 5 therefore also represent derivation from Rockall Bank metamorphics.

During the NP9 and NP10 times, sedimentation was dominated by the Greenland source, with Rockall-derived sediment restricted to Site 555, and even here brief influxes of Greenland detritus occur. Towards the end of NP10 times a major change in paleogeography took place, caused by the separation of Rockall and Greenland. This cut off sediment supply from the Greenland source and initiated the rapid subsidence of the continental margins.
In the phase immediately following the initiation of spreading, only Site 555 received significant amounts of fresh terrigenous sediment, with heavy minerals at the other sites being scarce and possible reworked. However in NP11 times sediments of basaltic origin, derived from the northern Rockall Plateau, reached the basin.

\section{ACKNOWLEDGMENTS}

The author is grateful to the U.K. Department of Energy for funding ship- and shore-based research. This paper is published with permission of the Director, British Geological Survey (N.E.R.C.).

\section{REFERENCES}

Carruthers, J. N., Cole, A. J., and Sollas, W. J., 1923. Notes on some rock fragments dredged up between Faeroe Bank and Rockall by the Research Vessel S. T. George Bligh during April 1921. Geol. Mag., 60:462-467.

Costa, L. I., and Downie, C., 1979. Cenozoic dinocyst stratigraphy of Sites 403 to 406 (Rockall Plateau), IPOD, Leg 48. In Montadert, L., Roberts, D. G., et al., Init. Repts. DSDP, 48: Washington (U.S. Govt. Printing Office), 513-522.

Crommelin, R. D., 1937. A sedimentary petrological investigation of a number of sand samples from the south coast of Greenland between Ivigtut and Frederiksdal. Medd. Gronland, 13:1-32.

Füchtbauer, H., 1970. Sandsteine, konglomerate und breccien. In Füchtbauer, H., and Müller, G. (Eds.), Sedimente und Sedimentgesteine: Stuttgart (Schweizarbart), pp. 12-129.

Galehouse, J. S., 1971. Point counting. In Carver, R. E. (Ed.), Procedures in Sedimentary Petrology: New York (Wiley-Interscience), pp. 385-407.

Gay, P., and Le Maitre, R. W., 1961. Some observations on "iddingsite." Am. Mineral., 46:92-111.

Hailwood, E. A., and Sayre, W. O., 1979. Magnetic anisotropy and sediment transport directions in North Atlantic early Cretaceous black shales and Eocene mudstones cored on DSDP Leg 48. In Montadert, L. and Roberts, D. G., et al., Init. Repts. DSDP, 48: Washington (U.S. Govt. Printing Office), 909-918.

Harrison, R. K., Knox, R. W. O'B., and Morton, A. C., 1979. Petrography and mineralogy of volcanogenic sediments from DSDP Leg 48, southwest Rockall Plateau, Sites 403 and 404. In Montadert, L., Roberts, D. G., et al., Init. Repts. DSDP, 48: Washington (U.S. Govt. Printing Office), 771-785.

Kerr, P. F., 1959. Optical Mineralogy: New York (McGraw-Hill).

Leake, B. E., 1978. Nomenclature of amphiboles. Am. Mineral., 63; 1023-1052.

Morton, A. C., 1979. Depth control of intrastratal solution of heavy minerals from the Palaeocene of the North Sea. J. Sediment. Petrol., 49:281-286.

1982. Lower Tertiary sand development in the Viking Graben, North Sea. Am. Assoc. Pet. Geol. Bull, 66:542-1559.

, in press. Stability of detrital heavy minerals in Tertiary sandstones of the North Sea Basin. Clay Min.

Müller, C., 1979. Calcareous nannofossils from the North Atlantic (Leg 48). In Montadert, L., Roberts, D. G., et al., Init. Repts. DSDP, 48: Washington (U.S. Govt. Printing Office), 589-639.

Poldervaart, A., and Hess, H. H., 1951. Pyroxenes in the crystallization of basaltic magma. J. Geol., 59:472-489.

Roberts, D. G., Matthews, D. H., and Eden, R. A., 1972. Metamorphic rocks from the southern end of the Rockall Bank. J. Geol. Soc. London, 128:501-506.

Roberts, D. G., Ardus, D. A., and Dearnley, R., 1973. Precambrian rocks drilled on the Rockall Bank. Nature, Phys. Sci., 244:21-23.

Roberts, D. G., Montadert, L., and Searle, R. C., 1979. The western Rockall Plateau: Stratigraphy and structural evolution. In Montadert, L., Roberts, D. G., et al., Init. Repts. DSDP, 48: Washington (U.S. Govt. Printing Office), 1061-1088.

Ross., C. S., and Shannon, E. V., 1925. The origin, occurrence, composition and physical properties of the mineral iddingsite. Proc. U.S. Nat. Mus., 67:1-19.

Sabine, P. A., 1972. Preliminary report on the basalt. In Laughton, A. S., Berggren, W. A., et al., Init. Repts. DSDP, 12: Washington (U.S. Govt. Printing Office), 407-410.

Date of Acceptance: August 5, 1983 